\title{
Nitroglycerin Stimulates Synthesis of Prostacyclin by Cultured Human Endothelial Cells
}

\author{
Richard I. LeVin, Eric A. JafFe, Babette B. Weksler, and \\ Karen TACK-Goldman, Division of Hematology-Oncology, \\ Department of Medicine, Cornell University Medical College, New York 10021
}

\begin{abstract}
A B S T R A C T Nitroglycerin (NTG), the agent most commonly used to treat acute angina pectoris, is a vasodilator whose mechanism of action remains unknown. We hypothesized that NTG might induce endothelial cells to synthesize prostacyclin $\left(\mathrm{PGI}_{2}\right)$, a known vasodilator and inhibitor of platelet aggregation. Therefore, cultured human endothelial cells were incubated with NTG at various concentrations for 1-3 min. $\mathrm{PGI}_{2}$ biologic activity in the endothelial cell supernates was assayed by inhibition of platelet aggregation in vitro. The concentration of 6 -keto-PGF ${ }_{1 \alpha}$, the stable hydrolysis product of $\mathrm{PGI}_{2}$, was measured by specific radioimmunoassay.
\end{abstract}

NTG alone significantly inhibited platelet aggregation and thromboxane $A_{2}$ synthesis only at suprapharmacologic concentrations $(\geq 1 \mu \mathrm{g} / \mathrm{ml})$. However, when NTG at clinically attainable concentrations $(0.1-10 \mathrm{ng} / \mathrm{ml})$ was incubated with endothelial cells, the endothelial cell supernates inhibited platelet aggregation in a dose-dependent manner. The inhibitor was heat labile. Radioimmunoassay of the endothelial cell supernates for 6-keto-PGF ${ }_{1 \alpha}$ demonstrated that NTG elicited dose-dependent increments in the synthesis of $\mathrm{PGI}_{2}$ by endothelial cells, ranging from $13 \%$ at NTG $10 \mathrm{pg} / \mathrm{ml}$ to $63 \%$ at NTG $10 \mathrm{ng} / \mathrm{ml}(P<0.01$, $n=10$ ). Pretreatment of endothelial cells with either aspirin $(50 \mu \mathrm{M}$ for $120 \mathrm{~min}$ ) or the prostacyclin synthetase inhibitor 15-hydroperoxyarachidonic acid

This paper was presented in part at the National Meeting of the American Society for Clinical Investigation, May 11, 1980, Washington, D. C.

Dr. Levin is the recipient of a National Institutes of Health Clinical Investigator Award (1 K08 HL00748) and is a member of the Visiting Faculty from the Cardiology Division, Department of Medicine, New York University School of Medicine. Dr. Jaffe is the recipient of a National Institutes of Health Research Career Development Award (5 K04 HL 00237) and a Career Scientist Award from the Irma $T$. Hirschl Trust. Dr. Weksler is the recipient of an American Cancer Society Faculty Research Award.

Received for publication 25 August 1980 and in revised form 10 November 1980.
(20 $\mu \mathrm{g} / \mathrm{ml}$ for $15 \mathrm{~min}$ ) abolished production of the platelet inhibitory substance. Synergy between NTG and $\mathrm{PGI}_{2}$ in the inhibition of platelet aggregation was not present at clinically attainable concentrations of NTG.

Thus, NTG at clinically attainable concentrations causes a dose-dependent increase in $\mathrm{PGI}_{2}$ synthesis by endothelial cells. If this phenomenon occurs in vivo, the $\mathrm{PGI}_{2}$ produced could ameliorate myocardial ischemia by causing peripheral vasodilation and decreasing cardiac work, inhibiting platelet aggregation and thromboxane $\mathrm{A}_{2}$ synthesis, and possibly reversing coronary artery vasospasm.

\section{INTRODUCTION}

Nitroglycerin (NTG) ${ }^{1}$ is a vasodilator of unknown mechanism which has been used clinically since 1855 for the treatment of angina pectoris (1). In addition to its vasodilating properties, NTG is an inhibitor of platelet aggregation in vitro, though only at high, suprapharmacologic concentrations (2-4). Thus, it belongs to a diverse group of agents including alcohol, dipyridamole, nitroprusside, verapamil, hydralazine, and others, which have both vasodilatory and antiplatelet activities (5-8).

It has been noted by Garratini (5) that for many of these drugs, there is a marked disparity between concentrations which inhibit platelet aggregation in vitro and therapeutic plasma levels obtained in vivo. The minimal in vitro inhibitory levels can be several orders of magnitude higher than the in vivo counterparts. Thus, if these agents inhibit platelet activity in vivo when used therapeutically, they must act indirectly. The mechanism of that action may also be responsible for the vasodilation. We hypothesized that NTG might stimulate the production of a second substance in vivo

${ }^{1}$ Abbreviations used in this paper: AA, arachidonic acid; ASA, aspirin; NTG, nitroglycerin; PG, prostaglandin; $\mathrm{PGI}_{2}$, prostacyclin; PRP, platelet-rich plasma; RIA, radioimmunoassay; TX, thromboxane. 
which in turn would decrease vascular tone and inhibit platelet activity. Prostacyclin $\left(\mathrm{PGI}_{2}\right)$ is now well established as a potent, naturally occurring vasodilator and platelet inhibitor $(9,10)$. Its properties are thus identical to the class of agents noted above. Furthermore, $\mathrm{PGI}_{2}$ is produced by endothelial cells (11). We therefore postulated that NTG acts in vivo by stimulating the production of $\mathrm{PGI}_{2}$ by endothelial cells.

This paper demonstrates that NTG induces a significant and dose-related increase in endothelial cell $\mathrm{PGI}_{2}$ synthesis in vitro; the $\mathrm{PGI}_{2}$ produced inhibits platelet function.

\section{METHODS}

Cell culture technique. Human endothelial cells were obtained from umbilical cord veins and cultured in 24-well (16 mm Diam) cluster plates (Costar, Cambridge, Mass.) as described $(12,13)$. Cultures were used at confluency in the second or third serial passage. Cell counts were performed as described $(11,12)$ and any well containing cells $> \pm 10 \%$ of the mean cell count was rejected from further evaluation.

Human lung fibroblasts (GM 1380, Human Genetic Mutant Cell Repository, Institute for Medical Research, Camden, N. J.) were maintained in minimal essential medium (Flow Laboratories Inc., Rockville, Md.) with $20 \%$ fetal calf serum in T75 flasks until passage into 24-well cluster plates. Cultures were then used at confluency.

Treatment of endothelial cells with NTG. NTG as a sterile aqueous solution containing solely NTG $(0.5 \mathrm{mg} / \mathrm{ml})$ and lactose $(4.5 \mathrm{mg} / \mathrm{ml})$ was obtained as a gift from Eli Lilly \& Co., Indianapolis, Ind. Because of the recent demonstration that NTG is adsorbed to plastic, serial 10 -fold dilutions in sterile water were prepared in glass tubes immediately prior to use (14). Light-shielding was used although it has recently been shown that lactose-adsorbed, aqueous NTG solutions do not decompose in light (15).

Each monolayer of endothelial cells was washed twice with a buffer containing $10 \mathrm{mM}$ Hepes $\left(\mathrm{pH} 7.35\right.$ at $\left.37^{\circ} \mathrm{C}\right), 137$ $\mathrm{mM} \mathrm{NaCl}, 5 \mathrm{mM} \mathrm{KCl}, 1.8 \mathrm{mM} \mathrm{CaCl}, 1 \mathrm{mM} \mathrm{MgCl} 2$, and $5.5 \mathrm{mM}$ glucose (buffer I). The cultures were agitated as little as possible to prevent shear-induced $\mathrm{PGI}_{2}$ production. $490 \mu \mathrm{l}$ of this buffer and $10 \mu \mathrm{l}$ of NTG solution were mixed to yield final NTG concentrations of $100 \mathrm{fg} / \mathrm{ml}$ to $10 \mathrm{ng} / \mathrm{ml}$ and then placed over the endothelial cell monolayer immediately after the second wash. After it was determined in preliminary experiments that maximal $\mathrm{PGI}_{2}$ release was obtained after incubation for $3 \mathrm{~min}$ at $37^{\circ} \mathrm{C}$, all incubations were performed for $3 \mathrm{~min}$ at $37^{\circ} \mathrm{C}$. Supernates were then removed, rapidly frozen, and then stored at $-70^{\circ} \mathrm{C}$ until use.

In each experiment the following control incubations with endothelial cells were performed: (a) buffer I containing 20 $\mu \mathrm{M}$ sodium arachidonate (AA, Sigma Chemical Co., St. Louis, Mo.); (b) buffer alone; and (c) buffer containing $90 \mu \mathrm{g} / \mathrm{ml}$ lactose (the vehicle for NTG; Sigma Chemical Co.). In addition, NTG solutions were incubated in wells without endothelial cells, which had been treated identically (gelatincoated, medium-conditioned) to those containing cultured cells. Finally in each experiment, the NTG, AA and buffer solutions were each incubated with endothelial cells which had been pretreated with either aspirin (ASA) (Sigma Chemical Co.) or 15-hydroperoxy arachidonic acid (a gift from Dr. Aaron Marcus) by methods described (16, 17).

Platelet aggregation and thromboxane $B_{2}$ production. Platelet-rich plasma (PRP) was prepared from venous blood and aggregation studies performed by methods described (18). Inhibition of aggregation was quantitated either by expressing the increase in light transmission $5 \mathrm{~min}$ after the addition of the stimulus as a percentage of control (method A) or by determining the area under the curve from stimulus to the 5-min mark by planimetry (planimeter No. 123A, Dietzgen Corp., Des Plaines, Ill.) and expressing it as a percentage of the area under the control curve (method B) (19). Because of the length of experiments, control aggregations were performed every $15 \mathrm{~min}$ in each channel to verify stability of the platelet response.

For the measurement of platelet thromboxane (TX) $\mathrm{A}_{2}$ production, platelet samples were prepared by a modification of the method of Fitzpatrick and Gorman (20). 5 min after addition of the stimulus to each aggregation cuvette, a 100- $\mu$ l sample was removed, immediately added to $900 \mu$ l of buffer I containing indomethacin $2 \mu \mathrm{g} / \mathrm{ml}$, vortexed, and frozen in a dry ice-acetone bath at $-70^{\circ} \mathrm{C}$. Samples were subsequently thawed, spun at $12,500 \mathrm{~g}$ for $3 \mathrm{~min}$ and the supernates removed and stored at $-70^{\circ} \mathrm{C}$ for testing in the radioimmunoassay (RIA) for $\mathrm{TXB}_{2}$ as described below.

Studies on the platelet inhibitory effect of NTG. Inhibition of platelet aggregation by NTG was studied using the following aggregating agents (expressed as final concentration in the cuvette): (a) Sodium arachidonate (Sigma Chemical Co.), 0.1-0.2 mM; (b) Collagen (Hormon-Chemie, Munich, West Germany) 0.1-1 $\mu \mathrm{g} / \mathrm{ml}$; (c) ADP (Sigma Chemical Co.), 1-3 $\mu \mathrm{M}$; (d) Epinephrine (Parke-Davis \& Co., Detroit, Mich.) 1-2 $\mu \mathrm{M}$; and (e) U-44069 (Upjohn Co., Kalamazoo Mich.) 2.4-2.9 $\mu \mathrm{M}$. The threshold aggregating concentration of each agent was determined after incubating the PRP for 1-5 min with buffer I such that the final volume after all additions was $0.5 \mathrm{ml}$. Threshold was defined as the lowest concentration which caused $\geq 90 \%$ increase in light transmission at $5 \mathrm{~min}$. Varying concentrations of NTG were incubated with aliquots of PRP for 1-5 min. Threshold concentrations of each aggregating agent were then added and aggregation recorded.

Possible synergy between NTG and either synthetic $\mathrm{PGI}_{2}$ or 6-keto-prostaglandin (PG) $\mathrm{F}_{1 \alpha}$ (kindly provided by Dr. John Pike, Upjohn Co.) was studied in a similar manner by combining the agent in various concentrations before stimulation.

RIA for 6-keto-PGF $F_{1 \alpha}$ and TX $B_{2}$ conjugation and immunization. $10 \mathrm{mg}$ keyhole limpet hemocyanin (Pacific Bio-Marine Laboratories Inc., Venice, Calif., $\mathrm{E}_{0.1 \%}^{27 \%}=2.49$ ) was conjugated to $5 \mathrm{mg}$ 6-keto-PGF ${ }_{1 \alpha}$ (Upjohn Co.) using $10 \mathrm{mg}$ 1-ethyl-3, 3'dimethylaminopropyl carbodiimide HCl (Sigma Chemical Co.) according to the method of Fitzpatrick et al. (21). $200 \mu \mathrm{g}$ 6-keto-PGF $1{ }_{1 \alpha}$-keyhole limpet hemocyanin conjugate was emulsified with an equal volume of Freund's complete adjuvant (Difco Laboratories, Detroit, Mich.) and injected intradermally at multiple sites into New Zealand white rabbits. After $6 \mathrm{wk}$, the rabbits were injected intradermally with $100 \mu \mathrm{g}$ 6-keto-PGF ${ }_{1 \alpha}$-keyhole limpet hemocyanin conjugate emulsified with Freund's incomplete adjuvant (Difco Laboratories). The animals were bled 10-14 d later from the central ear artery and the serum tested. The rabbits were injected thereafter with $100 \mu \mathrm{g}$ 6-keto-PGF ${ }_{1 \alpha}$ keyhole limpet hemocyanin conjugate in Freund's incomplete adjuvant at monthly intervals until the titers dropped.

The conjugation and immunization protocol for $\mathrm{TXB}_{2}$ antibody were similar except that the collected rabbits' blood was anticoagulated with EDTA and $0.1 \mathrm{mM}$ indomethacin at $4^{\circ} \mathrm{C}$ and centrifuged at $3,000 \mathrm{rpm}$ for $15 \mathrm{~min}$ at $4^{\circ} \mathrm{C}$. The plasma was removed and recalcified before use.

RIA. The RIA for 6-keto-PGF Pas $_{1 \alpha}$ wasformed as follows. $0.1 \mathrm{ml}$ of diluted $\left[{ }^{3} \mathrm{H}\right] 6-$-keto-PGF ${ }_{1 \alpha}(100 \mathrm{Ci} / \mathrm{mmol}$, New 
England Nuclear, Boston, Mass.) containing 10,000 dpm and $0.1 \mathrm{ml}$ of test sample (diluted when necessary with buffer I) were mixed in Eppendorf $1.5 \mathrm{ml}$ polypropylene test tubes. Purity of $\left[{ }^{3} \mathrm{H}\right] 6$-keto- $\mathrm{PGF}_{1 \alpha}$ was verified by thin-layer chromatography. $0.1 \mathrm{ml}$ of anti-6-keto-PGF ${ }_{1 \alpha}$ antisera diluted 1:3,200 with buffer II (50 mM Hepes, pH 7.5, $0.2 \%$ bovine serum albumin, and $0.02 \%$ sodium azide) was then added and the mixture incubated for $24 \mathrm{~h}$ at room temperature. Preliminary tests showed that this time was sufficient to yield a maximal binding of the antibody to the $\left[{ }^{3} \mathrm{H}\right] 6-$ ketoPGF $_{1 \alpha}$. Formalin fixed Staphylococcus aureus cowan type I (Pansorbin, Calbiochem-Behring Corp., American Hoechst Corp., San Diego, Calif.) were then added (100 $\mu$ l of a $1 \%$ suspension) and the mixture incubated for $30 \mathrm{~min}$ at room temperature. The mixture was centrifuged at $2,500 \mathrm{rpm}$ for $30 \mathrm{~min} .300 \mu \mathrm{l}$ of the total $400 \mu \mathrm{l}$ were removed and counted in a liquid scintillation counter. A standard curve (containing $1-2,000 \mathrm{pg} /$ tube of authentic 6 -keto- $\mathrm{PGF}_{1 \alpha}$ ) was run with every assay as were controls to check that the $S$. aureus was present in excess to bind all the antibody added. Standards were assayed in triplicate and unknowns were assayed at two different dilutions, each in duplicate. The data was analyzed using the four parameter logistic method of Rodbard and Hutt (22)

$50 \%$ inhibition of binding was reached at 50-60 pg and the range of sensitivity was $3-1,000 \mathrm{pg}$. Cross reactivities were as follows: $\mathrm{PGI}_{2}-100 \%$; 6,15-diketo-PGF ${ }_{1 \alpha}-1.3 \%$, 6-keto$\mathrm{PGE}_{1}-1.1 \%$, 13,14-dihydro-6,15-diketo-PGF $1 \alpha^{-1 \%}, \mathrm{PGF}_{2 \alpha^{-}}$ $0.1 \%$; $\mathrm{PGF}_{1 \alpha}, \mathrm{PGE}_{1}, \mathrm{PGE}_{2}, \mathrm{PGD}_{2}, \mathrm{TXB}_{2}$-all $<0.1 \%$.

Because of the presence of human serum in samples of the $\mathrm{TXB}_{2}$ radioimmunoassay, a double antibody technique using goat anti-rabbit immunoglobulin (Ig)G bound to beads (Immunobead second antibody, Bio-Rad Laboratories, Richmond, Calif.) was used. The TXB 2 RIA using $\left[{ }^{3} \mathrm{H}^{\mathrm{T}} \mathrm{TXB}_{2}\right.$ (New England Nuclear, $150 \mathrm{Ci} / \mathrm{mmol}$ ) and anti-sera at 1:4800 was otherwise performed in the same way as the 6-keto$\mathrm{PGF}_{1 \alpha}$ radioimmunoassay described above. The range of sensitivity for $\mathrm{TXB}_{2}$ was $3-1,000$ pg with $50 \%$ binding at $30-40 \mathrm{pg}$. Cross reactivities were as follows: $\mathrm{PGF}_{2}, 0.6 \%$, $0.06 \% ; \mathrm{PGF}_{2 \alpha}, 0.5 \%, \mathrm{PGE}_{1}, 0.2 \%$; 6-keto-PGF ${ }_{1 \alpha}$ and 6-keto$\mathrm{PGE}_{1}$ both $<0.02 \% ; 13,14$ dihydro $6,15-$ diketo-PGF $\mathrm{F}_{1 \alpha}$ both $\ll 0.02 \%$.

Sample preparation for RIA. Samples were thawed and allowed to incubate at room temperature for $2 \mathrm{~h}$. Dilutions were made as necessary with buffer $I$ at the time of the assay. Results are expressed as nanograms of 6-keto-PGF $F_{1 \alpha}$ per milliliter in each sample.
Statistical analysis. Statistical analysis was performed on an HP 9815 A computer (Hewlett-Packard Co., Palo Alto, Calif.) using prepared programs in volumes I and II of the HP statistics library (09815-15001) for the $t$ test and twoand three-way analyses of variance (23).

\section{RESULTS}

NTG as a direct inhibitor of platelet aggregation. NTG inhibited platelet aggregation in vitro only at very high final concentrations. Table I summarizes a series of experiments in which PRP was preincubated for 1 min with NTG and compares the sensitivity of aggregation induced by various aggregating agents to the direct inhibitory effect of NTG. Whereas varying patterns of sensitivity of these agents to the inhibitory effect of NTG were noted, significant inhibition of aggregation occurred only at concentrations of NTG $\geq 100 \mathrm{ng} / \mathrm{ml}$. NTG inhibition of aggregation was both time- and dosedependent with longer incubations causing greater inhibition at any given NTG concentration $\geq 100 \mathrm{ng} / \mathrm{ml}$ (data not shown). This finding is in agreement with data recently published by Schafer et al. (4).

To determine whether NTG inhibited platelet $\mathrm{TXA}_{2}$ production, RIA for $\mathrm{TXB}_{2}$, the stable end product of $\mathrm{TXA}_{2}$, was performed on samples of PRP treated with various concentrations of NTG. The results are shown in Fig. 1. NTG caused a statistically significant decrease in $\mathrm{TXB}_{2}$ production only at concentrations of NTG $\geq 100 \mathrm{ng} / \mathrm{ml}$, which as shown in Table I, parallels the inhibition of platelet aggregation. Studies in ASA-treated platelets demonstrated that NTG also inhibited primary phase aggregation induced by collagen, epinephrine, or U-44069 (data not shown). Thus, it is likely that NTG does not inhibit TXA 2 synthesis directly, but rather the inhibition is secondary to some other platelet inhibitory effect.

As shown in Table I and Fig. 1 neither platelet aggregation nor $\mathrm{TXB}_{2}$ synthesis was significantly inhibited at concentrations of NTG $<100 \mathrm{ng} / \mathrm{ml}$. How-

TABLE I

Inhibition of Platelet Aggregation by Nitroglycerin

\begin{tabular}{rrrrrr}
\hline \multicolumn{7}{c}{ Aggregating agent } \\
\hline NTG & AA & U-44069 & ADP & Epinephrine & Collagen \\
\hline$n g / m l$ & & $\%$ inhibition \\
10 & $0 \pm 0(4)$ & $1 \pm 9(3)$ & $0 \pm 20(3)$ & $1 \pm 3(3)$ & $1 \pm 3(9)$ \\
100 & $2 \pm 5(5)$ & $22 \pm 2(3)$ & $39 \pm 6(3)$ & $7 \pm 9(3)$ & $4 \pm 5(11)$ \\
1,000 & $89 \pm 3(5)$ & $50 \pm 2(3)$ & $59 \pm 4(3)$ & $50 \pm 12(3)$ & $7 \pm 9(11)$ \\
10,000 & $100 \pm 0(6)$ & $100 \pm 0(3)$ & $64 \pm 3(3)$ & $70 \pm 10(3)$ & $68 \pm 13(9)$ \\
50,000 & - & - & - & - & $94 \pm 4(9)$
\end{tabular}

After establishing the aggregation threshold for each agent, PRP was incubated for $1 \mathrm{~min}$ with NTG at the final concentrations listed. Results are expressed as percent inhibition of platelet aggregation compared to control without NTG. Numbers in parentheses indicate the number of samples tested. Inhibition was determined by method $A$ for epinephrine and collagen and method B for AA, U-44069, and ADP (Methods). U-44069, the endoperoxide analog. 


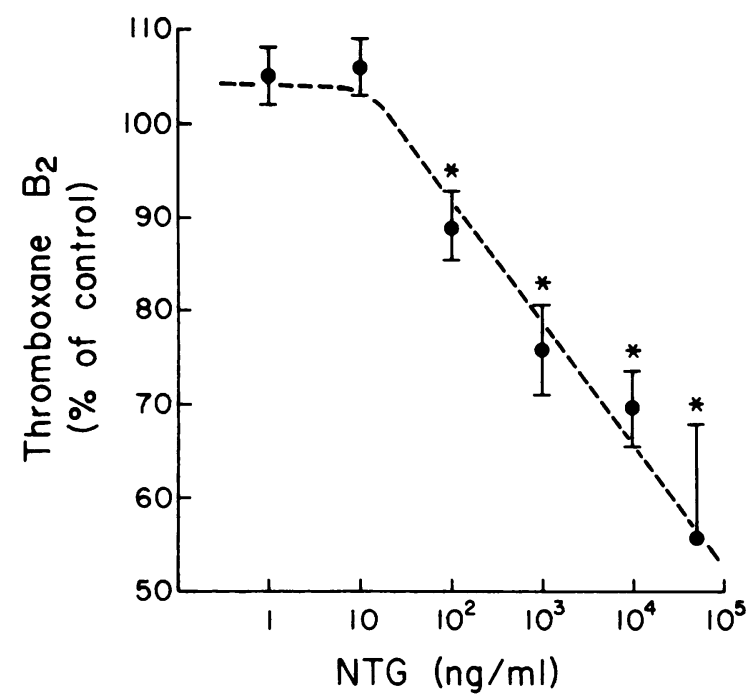

FIGURE 1 Inhibition of platelet $\mathrm{TXB}_{2}$ production by NTG. PRP was preincubated with either buffer I alone or NTG at the concentrations listed for $1 \mathrm{~min}$. Aggregation was then induced with a threshold dose of collagen. After $5 \mathrm{~min}$, an aliquot of PRP was removed and analyzed by RIA for TXB ${ }_{2}$. The results are expressed as a percentage of control in which no NTG was added (mean \pm SEM, $n=6-8$ depending on concentration of NTG). Statistical analysis comparing the decrease in $\mathrm{TXB}_{2}$ produced to controls was performed by Student's $t$ test. ${ }^{*} P \geq 0.0001$.

ever, after therapeutic cutaneous, sublingual, or intravenous administration of NTG in man, plasma levels of NTG peak below $10 \mathrm{ng} / \mathrm{ml}(24-28)$ except in severe congestive heart failure. Further, the only other clinical circumstance in which higher levels of NTG might be transiently achieved is during bolus infusion into coronary arteries during cardiac catheterization. Therefore, the direct inhibitory effect of NTG on platelet aggregation in vitro occurs only at suprapharmacologic concentrations, and with the exceptions noted, NTG concentrations achieved in vivo would not be expected to directly affect platelet aggregation or TXA $_{2}$ synthesis.

Inhibition of platelet aggregation by supernates from NTG-treated endothelial cells is related to enhancement of $P G I_{2}$ production. Fig. 2 displays the results of an individual experiment in which PRP was preincubated with supernates obtained from endothelial cells treated with NTG at pharmacologic concentrations and platelet aggregation then induced by adding collagen. A 3-min exposure of endothelial cells to NTG at clinically attainable concentrations of $0.1-10 \mathrm{ng} / \mathrm{ml}$ resulted in a dose-dependent production in the endothelial cell supernate of an inhibitor of platelet aggregation. The inhibition of platelet aggregation was seen at final concentrations of NTG in the PRP ( $1 / 10$ the original concentration) that do not directly inhibit platelet aggregation, as demonstrated in the previous section.

RIA of each of the endothelial cell supernates for

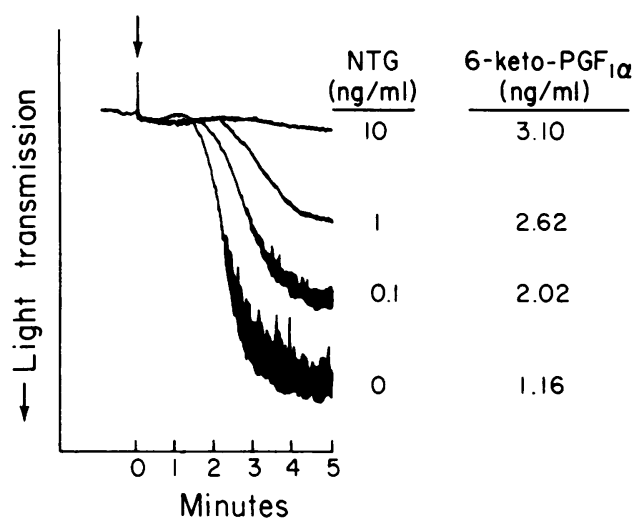

FIGURE 2 Inhibition of collagen-induced platelet aggregation by supernates from NTG-treated endothelial cells is related to an increase in $\mathrm{PGI}_{2}$ production. PRP was preincubated for $1 \mathrm{~min}$ with supernates from NTG-treated endothelial cells and collagen was then added (arrow). The concentration of NTG shown for each curve is that concentration used to treat the endothelial cells. The final concentration in the PRP (resulting from dilution of $50 \mu \mathrm{l}$ of supernate into $450 \mu \mathrm{l}$ of PRP) was $1 / 10$ that shown. The curve labeled $0 \mathrm{ng} / \mathrm{ml}$ represents the effect of the supernate from endothelial cells incubated with buffer I containing lactose (used as the vehicle for NTG). This curve is identical to the control curve (not shown) containing no endothelial cell supernate. Samples of the endothelial cell supernates were also analyzed for 6keto-PGF Py $_{1 \alpha}$ bIA. The results are listed and represent the concentration of 6-keto-PGF ${ }_{1 \alpha}$ in the endothelial cell supernate. The concentration of $\mathrm{PGI}_{2}$ present in the PRP was $1 / 10$ that shown due to dilution (see above).

6-keto-PGF $\mathrm{F}_{1 \alpha}$, the stable, spontaneous hydrolysis product of $\mathrm{PGI}_{2}$, demonstrated a NTG dose-dependent increase in $\mathrm{PGI}_{2}$ production by the endothelial cells (Fig. 2). For example, exposure of endothelial cells to $10 \mathrm{ng} / \mathrm{ml}$ NTG in buffer I for $3 \mathrm{~min}$ resulted in the production of $3.1 \mathrm{ng} / \mathrm{ml} 6$-keto-PGF $1 \alpha$, a $276 \%$ increase compared to the buffer control. This supernate caused a $97 \%$ inhibition of platelet aggregation. Lower doses of NTG elicited production of smaller amounts of 6-keto-PGF $\mathrm{P}_{1 \alpha}$ and were associated with correspondingly lesser degrees of inhibition of platelet aggregation. Whereas control endothelial cells synthesized $1.16 \mathrm{ng} / \mathrm{ml}$ 6-keto-PGF ${ }_{1 \alpha}$, this endothelial cell supernate did not inhibit platelet aggregation because the final concentration of $\mathrm{PGI}_{2}$ in the aggregation cuvette is only $1 / 10$ that in the endothelial cell supernate due to dilution. Thus, the concentration range of endothelial cell-synthesized $\mathrm{PGI}_{2}$ (measured as 6-keto$\mathrm{PGF}_{1 \alpha}$ ) in these experiments that caused inhibition of platelet aggregation is very similar to that reported by others $(10,29)$ and also obtained by us using synthetic $\mathrm{PGI}_{2}$ (see below).

As a control, cultured human lung fibroblasts (GM 1380) previously shown to be capable of synthesizing $\mathrm{PGI}_{2}$ (11) were treated either with NTG or with AA in a manner identical to that for endothelial cells. The supernatant fluids from AA-treated fibroblasts 
inhibited platelet aggregation and contained $13 \mathrm{ng}$ 6 -keto-PGF 10 / $10^{6}$ cells as determined by RIA. However, fibroblasts treated with NTG did not inhibit aggregation and contained 1-14 pg 6-keto- $\mathrm{PGF}_{10} / 10^{6}$ cells, which was not greater than the buffer control. This demonstrates that the response to NTG is not a general response of all cells capable of synthesizing $\mathrm{PGI}_{2}$.

To verify that the inhibition of platelet aggregation by supernates of NTG-treated endothelial cells depends on the presence of $\mathrm{PGI}_{2}$, a series of control experiments was performed. When endothelial cell cyclooxygenase was inactivated by pretreatment with $50 \mu \mathrm{M}$ ASA for $2 \mathrm{~h}$ (16), production of the inhibitor elicited from endothelial cells by NTG was completely suppressed; RIA of the supernate showed that 6-ketoPGF $_{1 \alpha}$ production was inhibited by more than $95 \%$. Inhibition of $\mathrm{PGI}_{2}$ synthetase by preincubation of endothelial cells with $20 \mu \mathrm{g} / \mathrm{ml}$ 15-hydroperoxy-AA for $15 \mathrm{~min}$ also completely abolished production of the inhibitor and RIA of these supernates showed $>85 \%$ inhibition of NTG-induced $\mathrm{PGI}_{2}$ production. On the basis of these results, it is concluded that the inhibitory effect of the supernates of NTG-exposed endothelial cells depends on $\mathrm{PGI}_{2}$. Furthermore, the inhibitor in these supernates was not generated by exposure to the endothelial cells to the buffer-vehicle alone and RIA demonstrated subinhibitory concentrations of 6-keto-PGF ${ }_{1 \alpha}$ in these samples. Finally, NTG alone after incubation in buffer $I$ in cell-free gelatin coated, medium conditioned wells did not inhibit platelet aggregation.

A heat lability study was performed to further characterize the inhibitor. Because it has been shown that endothelial cells incubated with AA produce $\mathrm{PGI}_{2}$ (11, 17), we compared the decay rates at $37^{\circ} \mathrm{C}$ of inhibitors in supernates from endothelial cells treated with NTG or with AA. The decay rates of the two inhibitors of platelet aggregation were identical (data not shown), further suggesting that the inhibitor in NTG-treated endothelial cell supernates is $\mathrm{PGI}_{2}$.

The dose-response relationship between NTG and 6-keto-PGF $\mathrm{F}_{1 \alpha}$ production by endothelial cells was obtained by combining the data from six separate experiments and is shown in Fig. 3. The amount of 6-keto$\mathrm{PGF}_{1 \alpha}$ produced was significantly greater than control $(P<0.01)$ at all NTG concentrations $\geq 0.1 \mathrm{ng} / \mathrm{ml}$. For example, NTG $10 \mathrm{ng} / \mathrm{ml}$ increased 6-keto-PGF ${ }_{1 \alpha}$ production by a mean value of $63 \%$. Lower doses of NTG elicited production of smaller amounts of 6-keto$\mathrm{PGF}_{1 \alpha}$. Samples from these six experiments were also tested for the presence of $\mathrm{PGI}_{2}$ biologic activity. Supernates from endothelial cells treated with NTG at concentrations $\geq 10 \mathrm{pg} / \mathrm{ml}$ incubated with PRP for 1 min significantly inhibited collagen-induced platelet aggregation $(P<0.001, n=10)$. Similar inhibition was obtained using AA or epinephrine as the aggregating

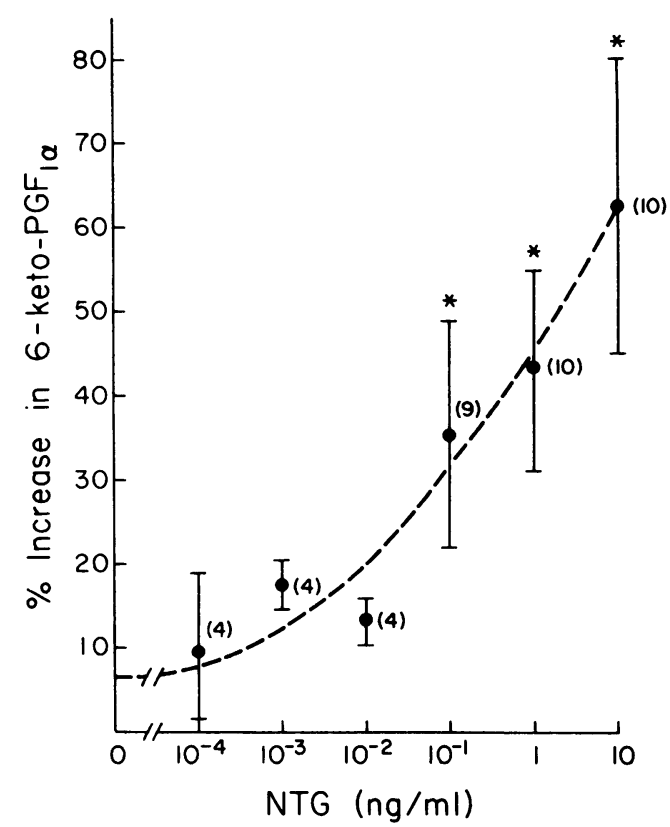

Figure 3 Dose-response relation between NTG and 6-keto$\mathrm{PGF}_{1 \alpha}$ production by endothelial cells. Endothelial cell monolayers were treated for $3 \mathrm{~min}$ at $37^{\circ} \mathrm{C}$ with NTG (0-10 $\mathrm{ng} / \mathrm{ml}$ ) and the concentration of 6-keto- $\mathrm{PGF}_{1 \alpha}$ in each supernate was then determined by RIA. The results are expressed as percent increase in production of 6-keto-PGF $1 \alpha$ compared to the buffer-lactose controls performed in each experiment (mean \pm SEM; number in parentheses). Statistical analysis comparing the increment of 6-keto- $\mathrm{PGF}_{1 \alpha}$ at each dose of NTG to the buffer-lactose controls was performed by Student's $t$ test. ${ }^{*} P \leq 0.01$.

agents. As noted, pretreatment of the endothelial cells with either ASA or 15-hydroperoxy-AA completely abolished the production of the inhibitor of platelet aggregation and the production of 6-keto-PGF ${ }_{1 \alpha}$.

To determine if there were any interactions between NTG, PGI $_{2}$, and endothelial cells that might have led to artifactual results in the RIA for 6-keto-PGF $F_{1 \alpha}$, a series of recovery studies were performed. Synthetic $\mathrm{PGI}_{2}(300-1200 \mathrm{pg} / \mathrm{ml})$ was incubated in triplicate in cluster plates under four conditions: $(a)$ in buffer I in cell-free wells; $(b)$ in buffer I overlying ASA-treated endothelial cells; $(c)$ in buffer I containing NTG at varying concentrations in cell-free wells; and $(d)$ in buffer I containing NTG overlying ASA-treated endothelial cells. Recovery was virtually identical under the four conditions. When these data were analyzed by a three-way analysis of variance (the three factors being $\mathrm{PGI}_{2}, \mathrm{NTG}$, and ASA-treated endothelial cells), the only factor that significantly affected the amount of 6-keto-PGF ${ }_{1 \alpha}$ recovered was the amount of $\mathrm{PGI}_{2}$ added $(P<0.0001)$. Neither NTG $(P=0.363)$ nor the presence of ASA-treated endothelial cells $(P=0.63)$ altered the recovery of 6-keto-PGF ${ }_{1 \alpha}$. Further, none of the possible two-way interactions nor the three-way interaction was statistically significant. Thus, neither NTG, endothelial cells, nor their combination caused 
an alteration in immunologically assayable 6-keto$\mathrm{PGF}_{1 \alpha}$.

Synergy of NTG and $\mathrm{PGI}_{2}$ in the inhibition of platelet aggregation. It has recently been reported that NTG at suprapharmacologic concentrations $(>1$ $\mu \mathrm{g} / \mathrm{ml}$ ) is synergistic with $\mathrm{PGI}_{2}$ in the inhibition of platelet aggregation in guinea-pig PRP (30). Therefore, we investigated the possibility that synergy was contributing to the inhibition of platelet aggregation in our experiments by studying the ability of combinations of synthetic $\mathrm{PGI}_{2}$ and NTG to inhibit aggregation in PRP. When suprapharmacologic doses of NTG $(\geq 1$ $\mu \mathrm{g} / \mathrm{ml}$ ) were combined with doses of $\mathrm{PGI}_{2}$ that alone inhibited platelet aggregation $8-67 \%(0.6-1.5 \mathrm{nM}$ or $0.21-0.52 \mathrm{ng} / \mathrm{ml}$ ), the combinations synergistically inhibited platelet aggregation in six separate experiments (in all experiments the test for synergy (interaction) by two-way analysis of variance was significant $P<0.01)$. However, in five experiments, when NTG at pharmacologic doses $(0.1-10 \mathrm{ng} / \mathrm{ml})$ was combined with these concentrations of $\mathrm{PGI}_{2}$, the combinations did not exhibit synergy in inhibiting aggregation. When these data were analyzed by two-way analysis of variance, the only significant factor affecting aggregation was the concentration of $\mathrm{PGI}_{2}(P \leq 0.0001$, five experiments). Neither NTG ( $P>0.2$, five experiments) nor the interaction of NTG and $\mathrm{PGI}_{2}(P=0.06-0.92,5$ experiments) altered the extent of aggregation. Thus, the inhibition of platelet aggregation caused by supernates of NTG-treated endothelial cells is not due to synergy between the NTG remaining in the supernate and the $\mathrm{PGI}_{2}$ produced by the endothelial cells.

Because of the possibility raised in recent reports $(31,32)$ that platelets might be capable of metabolizing inactive 6-keto-PGF ${ }_{1 \alpha}$ to the platelet inhibitor 6-keto$\mathrm{PGE}_{1}$, we also investigated whether NTG interacted with 6-keto-PGF $F_{1 \alpha}$ to inhibit aggregation. No inhibition of aggregation was noted when PRP was incubated either with 6-keto-PGF ${ }_{1 \alpha}$ alone or with 6-keto-PGF $F_{1 \alpha}$ and NTG for 1-30 min. This demonstrated that the inhibition of platelet aggregation by supernates of NTG-treated endothelial cells was not secondary to the conversion of 6 -keto- $\mathrm{PGF}_{1 \alpha}$ to some active inhibitory metabolite by the platelets.

\section{DISCUSSION}

In this paper, we have demonstrated that NTG at clinically attainable concentrations $(0.1-10 \mathrm{ng} / \mathrm{ml})$ induces a dose-dependent increase in endothelial cell $\mathrm{PGI}_{2}$ production in vitro, as measured both by RIA for 6-keto-PGF ${ }_{1 \alpha}$ and by inhibition of platelet aggregation. Pretreating the endothelial cells with either ASA or 15-hydroperoxy-AA blocked both the production of $\mathrm{PGI}_{2}$ as measured by RIA and the inhibition of platelet aggregation. These results also demonstrate that the inhibition of platelet aggregation by these endothelial cell supernates was not due to adenosine, another platelet inhibitory metabolite (33) released from endothelial cells by various stimuli (34), because treatment of endothelial cells with aspirin has no effect on their release of adenosine $(34,35)$. Heating the endothelial cell supernates at $37^{\circ} \mathrm{C}$, a condition known to inactivate $\mathrm{PGI}_{2}$ but not other platelet-inhibitory prostaglandins such as $\mathrm{PGE}_{1}$ or 6-keto $\operatorname{PGE}_{1}(32,36)$, inactivated the inhibitor. These experiments indicated that $\mathrm{PGI}_{2}$ was the inhibitor of platelet aggregation present in the supernates of NTGtreated endothelial cells.

We have further demonstrated that the observed inhibition of platelet aggregation by these supernates is not due to synergy between $\mathrm{PGI}_{2}$ and NTG remaining in the supernate, since $\mathrm{PGI}_{2}$ and NTG synergistically inhibit platelet aggregation only at suprapharmacologic concentrations of NTG. Since this synergy is not present in vitro at clinically attainable concentrations of NTG, it is unlikely to be present in vivo after therapeutic administration of the drug.

The inhibition of platelet aggregation caused by the supernates of NTG-treated endothelial cells was rarely total. However, it has been estimated that the ratio of endothelial cells to platelets in the capillary circulation is $\sim 1: 1$ (17). Our assay, because of a $1 / 10$ dilution of endothelial cell supernatants, matches the products of $10^{4}$ endothelial cells with an average of $1.2 \times 10^{8}$ platelets $(300,000 / \mathrm{mm} \cdot 400 \mu \mathrm{l})$, yielding an endothelial cell to platelet ratio of $1: 10,000$. If the ratio had been that found in vivo, i.e., $1: 1$, the concentration of $\mathrm{PGI}_{2}$ present would have been much higher and inhibition of platelet aggregation in vitro would have been complete, since even a twofold increase in $\mathrm{PGI}_{2}$ would have totally inhibited platelet aggregation.

Several studies have been performed attempting to demonstrate that NTG induces the production of $\mathrm{PGI}_{2}$ and other prostaglandins. Morcillio et al. (38) demonstrated that NTG, when infused into dogs, caused a decrease in coronary artery resistance which was accompanied by an increase in $\mathrm{E}$ series prostaglandins. Since indomethacin diminished both of these effects, it was suggested that NTG acted in part through the prostaglandin system. In contrast, Neichi et al. (39) were unable to demonstrate any effect of NTG $(100 \mu \mathrm{g} / \mathrm{ml})$ on $\mathrm{PGI}_{2}-\mathrm{TXA}_{2}$ synthesis using a coupled system of pig aortic microsomes and rat PRP. Forster $(30,40)$ while able to show that NTG $(>1 \mu \mathrm{g} / \mathrm{ml})$ caused an increase in coronary flow in isolated, perfused rat or guinea pig hearts, was unable to demonstrate an increase in $\mathrm{PGI}_{2}$ in the coronary effluent. Finally, Feigen et al. (41) were unable to prevent canine renal artery vasodilation induced by bolus injection of extremely high doses of NTG $(2-200 \mu \mathrm{g} / \mathrm{ml})$ after pretreatment of the animal with indomethacin or meclofenemate. There are several possible reasons for these negative results. First, the suprapharmacologic concentrations of NTG used ( $>1 \mu \mathrm{g} / \mathrm{ml}$ ) may 
have been toxic. Second, there may be species differences with respect to the NTG-PGI ${ }_{2}$ relationship. Third, intact endothelial cells, rather than microsomes, may be required for the action of NTG to be expressed. Finally, it is critical to recognize that at high, suprapharmacologic concentrations, NTG may have a direct effect on vascular smooth muscle (42), which is not mediated by $\mathrm{PGI}_{2}$ and is not seen clinically. This would be analogous to the direct inhibition of platelet aggregation by NTG at suprapharmacologic concentrations. Thus, the recent studies demonstrating that the plasma concentrations of NTG attained in man are 0.1 to $10 \mathrm{ng} / \mathrm{ml}(24,28)$ necessitate a reexamination of much of the in vitro data on the possible mechanism of action of NTG.

Current evidence suggests that NTG relieves ischemia primarily by reducing cardiac work as a result of peripheral vasodilation rather than by directly affecting the coronary circulation (42-45). NTG may also relieve angina by causing relaxation of coronary artery spasm (46), and by shifting blood flow from normally perfused to ischemic myocardium in the absence of peripherally mediated hemodynamic changes (47).

We have shown that intact monolayers of human endothelial cells in vitro release $\mathrm{PGI}_{2}$ in response to clinically attainable concentrations of NTG. The $\mathrm{PGI}_{2}$ produced inhibits platelet aggregation. These data suggest that the vasodilating properties of NTG noted above are, at least in part, indirect and due to the induction by NTG of endothelial cell $\mathrm{PGI}_{2}$ synthesis. The mechanism by which $\mathrm{PGI}_{2}$ induces vasodilation is unclear, though it may be related to its ability to alter eyclic nucleotide levels and calcium ion fluxes (48). Studies attempting to relate the direct effect of NTG to such alterations have thus far been inconclusive (49-54).

In conclusion, current available data suggest that the mechanism of NTG-induced vasodilation is multifactorial. The findings described here provided a basis for understanding in part how NTG might relieve myocardial ischemia by altering the $\mathrm{PGI}_{2}: \mathrm{TXA}_{2}$ ratio in favor of $\mathrm{PGI}_{2}$ excess with resultant vasodilation and inhibition of platelet function.

\section{ACKNOWLEDGMENTS}

We wish to express our appreciation to Charles Dorso and Sheldon Brown for technical assistance and to Naomi Nemtzow and Pauline Santos for preparation of the manuscript.

\section{REFERENCES}

1. Krantz, J. C. 1975. Historical Background. In Organic Nitrates. P. Needleman, editor. Handbook of Experimental Pharmacology. Springer-Verlag, New York. 40: 5-7.

2. Hampton, J. R., M. J. G. Harrison, A. J. Honour, and J. R. A. Mitchell. 1967. Platelet behavior and drugs used in cardiovascular disease. Cardiovasc. Res. 1: 101-107.
3. Synek, P., K. Rysanek, H. Spankova, and M. Mlejnkova. 1970. The effect of ethanol and nitroglycerin on platelet aggregation. Activitas Nervosa Superior. 12: 77-78.

4. Schafer, A. I., R. W. Alexander, and R. I. Handin. 1980. Inhibition of platelet function by organic nitrate vasodilators. Blood. 55: 649-654.

5. Garratini, S. G. 1978. Platelet-drug interactions: an open field. In Platelets: A Multidisciplinary Approach. Raven Press, New York. 61-73.

6. Burns, T. S., and R. N. Saunders. 1979. Antiplatelet activity of hydralazine. Thromb. Res. 16: 837-842.

7. Saxon, A., and Kattlove, H. E. 1976. Platelet inhibition by sodium nitroprusside, a smooth muscle inhibitor. Blood. 47: 957-961.

8. Lair, E. T., T. A. Ribeiro, J. K. Brandon, R. Horak, T. Solis, and R. R. Miller. 1980. Documentation of inhibition of platelet aggregation by verapamil: quantification by in vitro and in vivo techniques. Clin. Res. 28: 204A. (Abstr.)

9. Armstrong, J. M., N. Lattimer, S. Moncada, and J. R. Vane. 1978. Comparison of the vasodepressor effects of prostacyclin and 6-oxo-prostaglandin $F_{1 \alpha}$ with those of prostaglandin $\mathrm{E}_{2}$ in rats and rabbits. Br. J. Pharmacol. 62: 125-130.

10. Moncada, S., and J. R. Vane. 1978. Unstable metabolites of arachidonic acid and their role in haemostasis and thrombosis. Br. Med. Bull. 34: 129-136.

11. Weksler, B. B., A. J. Marcus, and E. A. Jaffe. 1977. Synthesis of prostaglandin $I_{2}$ (prostacyclin) by cultured human and bovine endothelial cells. Proc. Natl. Acad. Sci. U. S. A. 94: 3922-3926.

12. Jaffe, E. A., R. L. Nachman, C. G. Becker, and C. R. Minick. 1973. Culture of human endothelial cells derived from umbilical veins. J. Clin. Invest. 52: 2745-2756.

13. Jaffe, E. A., and D. F. Mosher. 1978. Synthesis of fibronectin by cultured human endothelial cells. J. Exp. Med. 147: 1779-1791.

14. Baaske, D. M., A. H. Amann, D. M. Wagenkneckt, M. Mooers, J. E. Carter, H. J. Hoyt, and R. G. Stoll. 1980. Nitroglycerin compatibility with intravenous fluid filters, containers, and administration sets. Am. J. Hosp. Pharm. 37: 201-205.

15. Sturek, J. K., T. D. Sokoloski, W. T. Winsley, and P. E. Stach. 1978. Stability of nitroglycerin injection determined by gas chromatography. Am. J. Hosp. Pharm. 35: 537-541.

16. Jaffe, E. A., and B. B. Weksler. 1979. Recovery of endothelial cell prostacyclin production after inhibition by low doses of aspirin. J. Clin. Invest. 63: 532-535.

17. Marcus, A. J., B. B. Weksler, and E. A. Jaffe. 1978. Enzymatic conversion of prostaglandin endoperoxide $\mathrm{H}_{2}$ and arachidonic acid to prostacyclin by cultured human endothelial cells. J. Biol. Chem. 253: 7138-7141.

18. Weksler, B. B., M. Gillick, and J. Pink. 1977. Effect of propranolol on platelet function. Blood. 49: 185-196.

19. Amezcua, J. L., J. O'Grady, J. A. Salmon, and S. Moncada. 1979. Prolonged paradoxical effect of aspirin on platelet behavior and bleeding time in man. Thromb. Res. 16: 67-79.

20. Fitzpatrick, F. A. and R. R. Gorman. 1978. A comparison of imidazole and 9,11-azoprosta-5,13-dienoic acid. Two selective thromboxane synthetase inhibitors. Biochim. Biophys. Acta. 539: 162-172.

21. Fitzpatrick, F. A., R. R. Gorman, J. C. McGuire, R. C. Kelly, M. A. Wynalda, and F. F. Sun. 1977. A radioimmunoassay for thromboxane $\mathrm{B}_{2}$. Anal. Biochem. 82: 1-7.

22. Rodbard, D., and D.M. Hutt. 1974. Statistical analysis of radioimmunoassays and immunoradiometric (labeled antibody) assays. A generalized weighted, iterative, least-squares method for logistic curve fitting. In Radio- 
immunoassay and Related Procedures in Medicine. International Atomic Energy Agency, Vienna. I: 165-192.

23. Snedecor, G. W., and W. G. Cochran. 1967. Chapter II In Statistical Methods. Iowa State University Press, Ames, Iowa. 6th Edition.

24. Bogaert, M. G., and M. T. Rosseel. 1972. Plasma levels in man of nitroglycerin after buccal administration. $J$. Pharm. Pharmacol. 24: 737-738.

25. Blumenthal, H. P., H. L. Fung, E. F. McNiff, and S. K. Yap. 1977. Plasma nitroglycerin levels after sublingual, oral, and topical administration. Br. J. Clin. Pharmac. 4: 241.

26. Armstrong, P. W., J. A. Armstrong, and G. S. Morris. 1979. Blood levels after sublingual nitroglycerin. Circulation. 59: 585-588.

27. Wei, J. Y., and P. R. Reid. 1979. Quantitative determination of trinitroglycerin in human plasma. Circulation. 59: 588-592.

28. Armstrong, P. W., J. A. Armstrong, and G. S. Marks. 1980. Pharmacokinetic-Hemodynamic studies of intravenous nitroglycerin in congestive cardiac failure. Circulation. 26: $160-166$.

29. DiMinno, G., M. J. Silver, and G. de Gaetano. 1979. Prostaglandins as inhibitors of human platelet aggregation. Br. J. Haematol. 43: 637-647.

30. Förster, W. 1980. Significance of prostaglandins and thromboxane $\mathrm{A}_{2}$ for the mode of action of cardiovascular drugs. In Advances in Prostaglandin and Thromboxane Research. B. Samuelsson, P. W. Ramwell, R. Paoletti, editors. Raven Press, New York. 7: 609-618.

31. Wong, P. Y.-K., W. H. Lee, P.H.-W. Chao, R. F. Reiss, and J. C. McGiff. 1980. Metabolism of prostacyclin by 9-hydroxyprostaglandin dehydrogenase in human platelets. J. Biol. Chem. 255: 9021-9024.

32. Wong, P. Y.-K., J. C. McGiff, F. F. Sun, and W. H. Lee. 1979. 6-Keto-Prostaglandin $E_{1}$ inhibits the aggregation of human platelets. Eur. J. Pharmacol. 60: 245-248.

33. Haslam, R. J., and G. M. Rosson. 1975. Effects of adenosine on levels of adenosine cyclic $3^{\prime}, 5^{\prime}$-monophosphate in human blood platelets in relation to adenosine incorporation and platelet aggregation. Mol. Pharmacol. 11: 528-544.

34. Pearson, J. D., and J. L. Gordon. 1979. Vascular cells and smooth muscle cells in culture selectively release adenine nucleotides. Nature (Lond.). 281: 384-386.

35. Crutchley, D. J., U. S. Ryan, and J. W. Ryan. 1980. Effects of aspirin and dipyridamole on the degradation of adenosine diphosphate by cultured cells derived from bovine pulmonary artery. J. Clin. Invest. 66: 29-35.

36. Moncada, S., P. Needleman, S. Bunting, and J. R. Vane. 1976. Prostaglandin endoperoxide and thromboxane generating systems and their selective inhibition. Prostaglandins. 12: 323-333.

37. Marcus, A. J., B. B. Weksler, E. A. Jaffe, and J. J. Broekman. 1980. Synthesis of prostacyclin from platelet-derived endoperoxides by cultured human endothelial cells. $J$. Clin. Invest. 66: 979-986.

38. Morcillio, E., P. R. Reid, H. Dubin, R. Ghadgaonkar, and B. Pitt. 1980. Myocardial prostaglandin E release by nitroglycerin and modification by indomethacin. Am.J. Cardiol. 45: 53-57.

39. Neichi, T., S. Tomisawa, N. Kubodera, and Y. Uchida. 1980. Enhancement of $\mathrm{PGI}_{2}$ formation by a new vasodilator, 2-nicotinamidoethylnitrate in the coupled system of platelets and aortic microsomes. Prostaglandins. 19: 577-586.

40. Förster, W. 1979. Prostaglandine, Thromboxan $A_{2}$ und Herz-Kreislauf-Pharmaka. Beiträge zur Wirkstofforschung, heft 6 aus dem Akademie-Industrie-Komplex Arzheimittel forschung. Berlin.

41. Feigen, L. P., B. M. Chapnick, J. E. Flemming, and P. J. Kadowitz. 1978. Prostaglandins: renal vascular responses to bradykinin, histamine, and nitroglycerine. Am. J. Physiol. 234: H496-H502.

42. Vatner, S. F., and G. R. Heyndrickx. 1975. Mechanism of action of nitroglycerin: coronary, cardiac, and systemic effects. In Organic Nitrates. P. Needleman, editor. Handbook of Experimental Pharmacology. SpringerVerlag, New York. 40: 131-161.

43. Ganz, W., and H. S. Marcus. 1972. Failure of nitroglycerin in alleviate pacing-induced angina. Circulation. 46: 880-889.

44. Vatner, S. F., C. G. Higgins, R. W. Millard, and D. Franklin. 1972. Direct and reflex effects of nitroglycerin on coronary and left ventricular dynamics in conscious dogs. J. Clin. Invest. 51: 2872-2882.

45. Hood, W. P., I. Amende, R. Simon, and P. R. Lichtlen. 1980. The effects of intracoronary nitroglycerin on left ventricular systolic and diastolic function in man. Circulation. 61: 1098-1104.

46. Oliva, P. B., and J. C. Breckinridge. 1977. Arteriographic evidence of coronary arterial spasm in acute myocardial infarction. Circulation. 56: 366-374.

47. Swain, J. L., J. P. Parker, P. A. McHale, and J. C. Greenfield, Jr. 1979. Effects of nitroglycerin and propranolol on the distribution of transmural myocardial blood flow during ischemia in the absence of hemodynamic changes in the unanesthesized dog. J. Clin. Invest. 63: 947-953.

48. Kukovetz, W. R., S. Holzmann, A. Wurm, and G. Poch. 1979. Prostacyclin increases cAMP in coronary arteries. J. Cyclic. Nucleotide. Res. 5: 469-476.

49. Axelsson, K. L., J. E. S. Wikborg, and R. G. L. Anderson 1979. Relationship between nitroglycerin, cyclic GMP, and relaxation of vascular smooth muscle. Life Sci. 24: 1779-1786.

50. Katsuki, S., W. P. Arnold, and F. Murad. 1977. Effects of sodium nitroprusside, nitroglycerin, and sodium azide on levels of cyclic nucleotides and mechanical activity of various tissues. J. Cyclic Nucleotide. Res. 3: 239-247.

51. Diamond, J., and K. S. Blisard. 1976. Effects of stimulant and relaxant drugs on tension and cyclic nucleotide levels in canine femoral artery. Mol. Pharmacol. 12: 688-692.

52. Ignarro, L. J., B. K. Barry, and C. A. Gruetter. 1980. Mechanism by which glyceryl trinitrate and sodium nitrite activate coronary arterial guanylate cyclase: involvement of novel 5-nitrosothiols as active intermediates. Clin. Res. 28: 728A. (Abstr.)

53. Harder, D. R., L. Belardinelli, N. Sperelakis, R. Rubio, and R. M. Berne. 1979. Differential effects of adenosine and nitroglycerin on the action potentials of large and small coronary arteries. Circ. Res. 44: 176-182.

54. Kreye, V. A. W. 1978. Organic Nitrates, Sodium Nitroprusside, and Vasodilation. In Mechanisms of Vasodilation. Satellite Symposium, 27th Int. Congress Physiol. Sci., Wilrijk, 1977. P. M. Vanhoutte and I. Leusen, editors. S. Karger, Basel, Switzerland. 158-164. 